\title{
A new perspective on vegetable oil epoxidation modeling: reaction and mass transfer in a liquid-liquid-solid system
}

\author{
Tapio Salmi ${ }^{1}$, Vincenzo Russo ${ }^{2}$, Adriana Aguilera ${ }^{1}$, Pasi Tolvanen ${ }^{1}$, Johan Wärnå ${ }^{1}$, Martino \\ Di Serio ${ }^{2}$, Riccardo Tesser ${ }^{2}$, Tommaso Cogliano ${ }^{2}$, Sebastien Leveneur ${ }^{3}$, and Kari Eränen ${ }^{1}$
}

\author{
${ }^{1}$ Abo Akademi \\ ${ }^{2}$ University of Naples Federico II \\ ${ }^{3}$ INSA de Rouen-LSPC
}

July 11, 2021

\begin{abstract}
A rigorous mathematical model was developed for a complex liquid-liquid-solid system in a batch reactor. The approach is general but particularly well applicable for the indirect epoxidation of vegetable oils according to the concept of N. Prileschajew. The model considers intra- and interfacial mass transfer effects coupled to the reaction kinetics. The liquid phases were described with chemical approach (aqueous phase) and a reaction-diffusion approach (oil phase). The oil droplets were treated as rigid spheres, in which the overall reaction rate is influenced by chemical reactions and molecular diffusion phenomena. The model was tested with a generic example, where two reactions proceeded simultaneously in the aqueous and oil phases. The example (i.e. fatty acid epoxidation à la Prileschajew) illustrated the power of the real multiphase model in epoxidation processes. The proposed modelling concept can be used for optimization purposes for many applications, which comprise a complex water-oil-solid catalyst system.
\end{abstract}

\section{Hosted file}

Manuscript.docx available at https://authorea.com/users/425054/articles/529973-a-newperspective-on-vegetable-oil-epoxidation-modeling-reaction-and-mass-transfer-in-aliquid-liquid-solid-system 